\title{
The Impact of Dialogue Journals on Student's Writing
}

\author{
Yina Carolina Murillo Zabala \\ University of Caldas, Manizales, Caldas-Colombia \\ Email: yicamuza[at]gamil.com
}

\begin{abstract}
The purpose of this research was to measure the impact of dialogue journals on student's writing. To achieve that goal, seventh graders between twelve and fourteen years old at San Rafael School in Valencia-Córdoba, learners were monitored in an EFL setting in order to determine how their writing abilities improved. Several strategies were implemented in class through writing activities led by a dialogue journal. This study was implemented at different stages: the diagnosis stage based on data collected from three instruments (survey, a test, and an interview) ; the action stage carried out through a series of class workshops; and the evaluation stage also based on three data-collection instruments incorporating (a teachers' diary, an outsider observation and a self-reflection questionnaire). The findings reported the usefulness of dialogue journals in the EFL classroom as a means to improve writing performance, vocabulary, and attitude of the participants. In conclusion, being conscious of the importance of using dialogue journals in classes, which demonstrate to be an efficient tool for learners to strengthen writing, learn vocabulary and increase confidence while writing, and at the same time, encouraging teachers know, analyze, use and implement new aspects when teaching children and teenagers how to write for communicate.
\end{abstract}

Keywords: Dialogue journals, writing activities, Students' L1 dependence, Vocabulary, Student's writing

\section{Introduction}

Many writing studies are commonly related with the Students' writing improvements, which, in turn, has been considerably a "vital skill for speakers of a foreign language as much as for everyone using their own first language." Harmer (2004: v). More specifically, research has demonstrated that Dialogue Journals are efficient tools for learners to improve their written ability, vocabulary, and grammar; they also lower their L1 dependence, since writing helps them to communicate and think more clearly in English. Studies about dialogue journals and student's writing have given learners and teachers different tools, ideas and suggestions for enhancing learners writing and the use of multiple writing strategies. Indeed, there are various works of research about the usefulness of dialogue journals on student's writing. Orem (2001) states that dialogue journals provide learners an opportunity to practice using the target language in meaningful and authentic contexts. However, since "the interactions are written", they allow students to use reading and writing in "distinct ways and provide a natural, comfortable bridge to other kinds of writing." (Peyton, 2000). This is the aim of this particular study:to measure the impact of dialogue journals on student's writing, perceived the foreign language learning difficulties of each participants. The questions guiding the current study are:

1) To what extent do dialogue journals have an impact on sixth grade students' writing skills at a public school in Valencia, Córdoba?

2) How dialogue journals help increase the English vocabulary of sixth graders?

3) How dialogue journals reduce the L1 dependence of the participants?

4) What students do to better grammar in the English class?

In what follows, Dialogue Journals are efficient tools for learners to improve their written ability, vocabulary, and grammar; they also lower their L1 dependence, since writing helps them to communicate and think more clearly in English. The section on literature review highlights the strengths of some recent studies but also discuss some of the gaps that our study intends to address.

\section{Literature Review}

Based on Dialogue journals, various important issues such as learners' writing abilities including grammar, content and lexical usage, and confidence in writing ability are developed (Peng, 2007), which are linked to help learners achieve autonomy, understand more about similar and different cultural backgrounds, and improve their reflective thinking (Trites,2001). Several studies have relied on dialogue journals as a useful for learners' reflective practice and teacher-and-learner interactive engagement (Carroll \& Mchawala, 2001; English \& Gillen, 2001; Peyton, 1993b, 2000; Peyton \& Reed, 1990; Peyton \& Staton, 1993; Reed, 1993; Trites, 2001.) Dialogue journals allow students to have a better writing progress by providing them with the opportunity to interact with their teacher and classmates. This confirms that dialogue journal contributes to learner interaction, letting students use reading and writing in "effective ways and provide a usual, comfortable bridge to alternative kinds of writing” (Peyton, 2000, p. 1).

Research on dialogue journals and student's writing has been important, principally the improvement of writing by using dialogue journals, the student's engagement with written -activities, their confidence while writing and monitoring their own progress. Studies have given learners and teachers different tools, ideas and suggestions for enhancing learners writing and the use of multiple writing strategies. Indeed, there are various works of research about the usefulness of dialogue journals on student's writing. Orem (2001) states that dialogue journals provide learners an opportunity to practice using the target language in

Volume 10 Issue 7, July 2021 


\section{International Journal of Science and Research (IJSR) \\ ISSN: 2319-7064 \\ SJIF (2020): 7.803}

meaningful and authentic contexts. However, since "the interactions are written", they allow students to use reading and writing in "distinct ways and provide a natural, comfortable bridge to other kinds of writing." (Peyton, 2000).

From a qualitative perspective, Dialogue journals give learners the opportunity to practice authentic language, increment learners' own motivation, develop writing and reading fluency, and develop close relationship between teachers and students (Kose, 2005). By making comments and asking questions about their students' entries, teachers can get more information about needs and have a wider view of writing performance. Indeed, teachers are capable to effectively look for more resources that will motivate the students directly with a foreign language (Han \& Stevenson, 2008). Furthermore, dialogue journals add written and close conversation between a teacher and a student, and increase learners' motivation, develop writing and reading fluency, and the teacher can notice writing mistakes and how to avoid them (Peyton \& Staton, 1993; Kose, 2005).

Many other studies affirm that, various important issues such as learners' writing abilities including grammar, content and lexical usage, and confidence in writing ability are developed (Peng, 2007). Regarding writing, dialogue journals provide students with essential opportunities to develop their writing and reading skills, giving them the opportunity for meaningful language use as well as capacities to enhance reflective thinking. Besides, through the use of dialogue journals, learners can participate in writing and reading in a natural way, letting them communicate with their teacher in a non-threatening environment. That is, learners' writing skills are reflected during the writing activities, the learning itself and confidence. Harmer (2007) states dialogue journals improves the students' writing skills and help them reflect on their learning during the written activities, and it can be a good writing practice too. (Haynes-Mays, 2011; Yoshihara, 2008) dialogue journals writing establishes a natural, comfortable bridge to different kinds of writing and provides opportunities for students to learn grammatical forms and structures by reading teachers' responses and imitating them.

To conclude, research has shown some benefits due to the use of dialogue journals as a way to improve learner's writing skills. However, these benefits should delve deeper and consider the students' levels of English and interests, which might affect results related to the effectiveness of the strategy. This study aims at contributing to this knowledge.

\section{Method}

\subsection{Participants and procedure}

Participants in this study included seventh- grade students at a public school in Valencia, Cordoba. They were 15 girls and 13 boys, whose ages ranged between 12 and 14 years old. Regarding learner's background knowledge in English, students had not been exposed to English since preschool and elementary school because they did not receive the number of hours as it is established in the Institutional
Educative Project of the school (IEP). Additionally, all of them were exposed to English as a foreign language from 6 th grade until now.

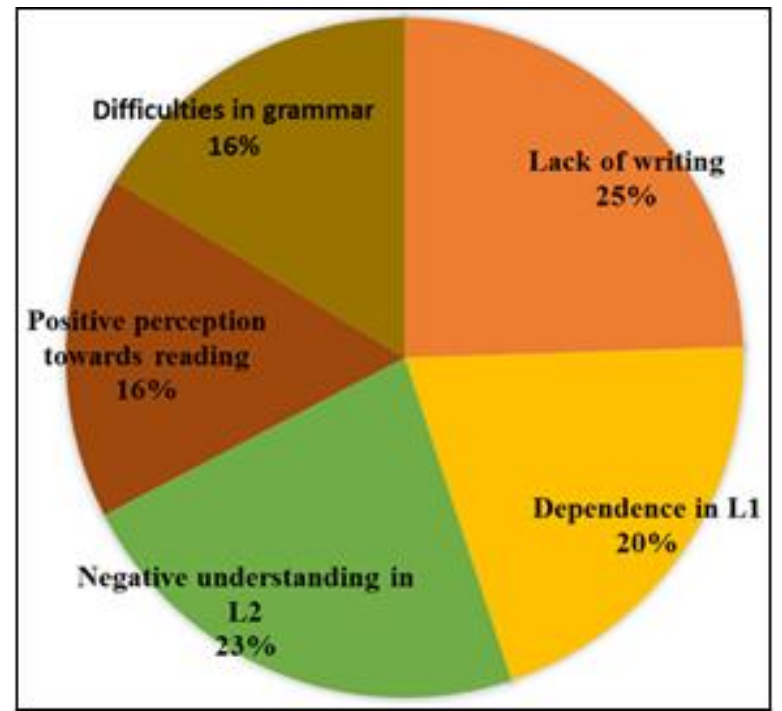

Figure 1: Result of categories found in each instrument

Figure 1 shows that the participants had weaknesses at the moment of doing an activity that involves written expression. Thus, there was an evident need in the design and implementation of some workshops to improve writing, so that learners had the opportunity to achieve better results. Since accurate vocabulary, writing strategies and grammar structures are needed to write coherent texts, Dialogue Journals could be an excellent option to help learners improve their writing performance. This tool could also give learners the possibility to learn vocabulary, grammar, raise their confidence, and express feelings related to their interest and desires.

\section{Instruments}

Some data collection instruments, incorporating a teacher's dairy, an outsider observation and a self-reflection questionnaire were used. Also, a diagnosis test was carried out to assess and measure learners' L2 writing before the intervention. Based on the results, workshops and lesson plans were designed.

\section{Research Journal}

A teacher's diary was completed with the most relevant aspects of the class, such as writing, grammar, vocabulary, spelling, writing content and dependence in L1. Besides, learners' performance in written activities during the class was mentioned. The information gathered included positive and negative aspects of the development of each workshop. This evidence provided significant information for use as an instrument for data collection, since the collected data would be helpful to the researcher and teacher.

\section{Outsider observation}

A non-participant observation was carried out; this person considered each of the aspects mentioned before to observe the learners' performance while writing during each task. Every fifteen days, the observations were made in each of the six workshops; the outsider observer provided extra comments related the students' participation and

\section{Volume 10 Issue 7, July 2021


performance with the implementation of dialogue journals strategy.

\section{Self-reflection questionnaire}

The self-reflection questionnaire was designed to know the learner's perception about their performance in each of the six workshops, in order to analyze the effectiveness of adding content strategy through writing. Said instrument had eight items, which gave students the chance to reflect upon their writing process in terms of vocabulary, grammar, writing content, spelling and decrease in L1 dependence. Students had to choose a happy or sad face, which represented a positive or negative reaction.

\section{Data analysis}

As a first step of the data analysis, a group of data collection instruments were designed and administered to describe how to collect data and code the information. In a second step, the research is made up of two different parts, one carried out in class, and the other one at home. In the former, a workshop was implemented during class time for the students to learn how to deal with writing processes, build confidence and develop writing and critical thinking (Seow, 2002). In the latter, that process in class was reinforced by implementing the students' dialogue journals in and outside the class in order to improve and reinforce writing practices.

\section{Results}

\section{Dialogue journals strategy and the improvement of vocabulary}

The data analysis showed that all of the learners achieved a progressive improvement in certain aspects of writing and one of them was vocabulary. Through the results gathered in the instruments and the scores obtained in the individual assessment rubrics, that improvement was evidenced in each stage. From the implementation of the first workshop, and after starting each one of the classes by introducing the vocabulary for students to learn it, they were able to use it in their written activities. In Excerpt 1, Teacher's diary showed that learners improved a little more on vocabulary, making new entries in their journals; however, they needed to work more on their meaning and use.

Excerpt 1: ["Students do not remember the vocabulary taught last class, for that reason many of them could not finish the activity on time, some of the students made good use of the vocabulary in their new journal entry"]

In Excerpt 2, teacher's diary and the outsider observation stated learner's difficulties with vocabulary-required practice through the good use of the writing strategy proposed by the teacher in the workshop, learners showed that it was not -easy for them to write meaningful complete sentences or to connect ideas in a short paragraph.

Excerpt 2: ["Students did not know how to use the vocabulary to describe their daily routine; they could not link words and expressions to describe their routine."'].... ["Students did not use the vocabulary taught in class","] In Excerpt 3, Teacher's diary pointed out the difficulties learners had while developing the activity. They were confused and were no able to solve the activity by themselves. However, after the explanation of the teacher, they completed the task and used the vocabulary corresponding each point.

Excerpt 3: ["At the beginning of the activity, students were confused with the vocabulary they did not how to match the place of work with the profession."]

In Excerpt 4, Students' diary evidenced they were able to use the vocabulary, but some of them rarely used the vocabulary in English, that is, they completed the written activities using the vocabulary and resorted to their native language.

Excerpt 4: ["I rarely used the vocabulary in English; I used it in my native language"]... ["I was confused with the vocabulary at the beginning of the class"]

Overall, pupils demonstrated that their vocabulary had increased progressively and, consequently, they were able to write topics of their interest by using the vocabulary learnt in class. As the findings showed, dialogue journals strategy had a positive effect on the learners because they were able to accurately use the vocabulary previously taught along the study and, later, they were also able to write long logical sentences, short paragraphs and new entries in their journals. Furthermore, dialogue journals strategy had a meaningful impact on students writing particularly on understanding reflections, responding or analyzing events, experiences or concepts (Ballantyne and packer, 1995). As Harmer (2007) stated, by providing opportunities for students to think both about how they are learning and also what they are learning, dialogue journals improve their writing skills and help them to reflect on their learning, and it can be a good writing practice too.

\section{Dialogue journals strategy and the improvement of grammar}

This section reports on one of the strategies used to provide students with collaborative learning is dialogue journal writing since it enhances students' writing abilities in terms of grammar structures, writing content and confidence in writing ability. The data analysis revealed that, students were able to improve grammatical forms, structures, and word order. However, it is important to highlight that dialogue journals were demanding and appealing for students. Additionally, during the implementation of workshops, the students were also able to use grammar, vocabulary, and their L1 language to complete all the written activities. Learners did so with the help of the teachers, later, on their own. In Excerpt 5, Learners were able to use grammar in their writings using most of the vocabulary they were taught during lessons. Besides, they linked words or groups of words while they were completing written tasks.

Excerpt 5: ["Students followed the instructions how they should write their routine" (Outsider observation).][ "I wrote my daily routine as the teacher explained. Beginning with I get up...I take a shower.... I go to school..." (Students' Selfreflection).] 
Excerpt 6:["Some of the students used the grammatical structures completed in class during the implementation of the written activities" (teacher's diary)]. ["We could use grammatical structures on my writing” (student's diary).] ["They could use grammatical structures taking into account the topic of the unit. Where do doctors...? They work..., most of them omitted some letters, but they could complete the task" (Outsider observation).]

As Excerpt 6 shows, learners wrote new entries in their journal diaries using grammatical structures previously taught, bearing in mind the topics and the way to answer the activities; that is, no matter whether they omitted some letters, they were able to complete the activity.

In excerpt 7, Learners improved the use of grammatical structures in the written activities. Besides, they joined words to create paragraphs with the teacher's help; additionally, they wrote sentences that made sense to express their ideas and, at the same time, used the grammatical structures learnt in class to complete the written activities, regardless of the misspelled words.

Excerpt 7: ["I used grammar to learn more English" (students' self- reflection)....] ["Students used the grammar structures explained before start the written activities; they were able to answer questions using third and first person" (Teacher's diary).]

Overall, students were bettering in writing through dialogue journal strategy. That is, learners used grammar structures: auxiliaries, verbs, expressions in their writings, using the aspects mentioned before to complete the activities. Learners made good use of grammar to complete the written activities and strengthen writing performance. Therefore, this strategy was useful to improve students' ability to write in a second language.

Excerpt 8: ["I used grammar on my written activity" (students' self-reflection questionnaire)]["Learners could use grammar in their writing" (teachers" diary)].

The findings in this section suggest that dialogue journals were used in order for pupils to evaluate their writing and learning processes. Through them, students developed awareness of their weaknesses and strengths in writing, achieved autonomy, understood more about grammar and linguistics aspects, and improved their reflective thinking. Trites (2001). However, some learners did not improve the same aspects as the rest of their classmates; they rather had lower scores in the individual rubrics than the other ones. It was evident that these learners had difficulties when using long sentences, word order, and spelling rules.

\section{Dialogue journals and students' $L 1$ dependence}

The current study examined whether learners needed to decrease L1 dependence while writing. Broadly, "ESL learners frequently resorted to their L1 organization skills in L2 writing" Berman (1994), it is to say, if while writing new entries in their dialogue journals in L2 language they did not know how to solve an activity or write a word, learners would find support in their L1 (L1 dependence) to complete the task. Thus, learners did not set L1 language aside during the English activities; they used it all time and were confident with its use.In excerpt 9, learners had difficulties while writing, because they employed all time their native language to create short paragraphs and complete sentences; but, during the activities done in class, learners did not decrease L1 dependence.

Excerpt 9: ["What's do you estudiante? (Students' diary)] ["What's your favorite futbol? (Students' diary)]

As excerpt 9 suggests, learners still used their native language in their journal entries. They combine English and Spanish at the same time to create a piece of text and use words that are written in the same way in both language, but sometimes, these words differ in meaning.Stressing the effects of their L1 learning experiences and L2 language, learners stated that the high personal value of L2 writing was partially influenced by their negative L1 writing experiences. That is, the relationship between L1 and L2 learning indicates how L1 dependence affects learning of another language. Furthermore, certain L1 linguistic knowledge and skills can be positively or negatively transferred during the process of L2 acquisition, and transfer happens automatically (Cummins, 1978). In relation to this, Husain (1995) claims that the use of L1 provides foreign language learners with a quick and efficient method for analyzing and comprehending the structure of the target language. Excerpt 10, shows how students had difficulties using L2 language; that is, they mixed L1 and L2 to create short paragraphs, answer questions, complete sentences, they felt more comfortable using L1 to complete the activities.

Excerpt 10: ["I used my native language in the English class; I used the vocabulary in spite of some words I did not identify" (student's diary)]....["My classmates and I used our L1 language to participate in the English class. Also, our teacher explains us in Spanish because we could not understand sometimes the class" (student's diary).]... [I siempre wrote vocabulary]. [I inglish class]

In Excerpt 11, Learners did not isolate L1 in their written texts. They used L1 during class participation and the development of activities all time. In addition, they continued having difficulties and because of that, they were using their L1 language with a high continuity.

Excerpt 11: [S13: My father is a fumigator/ L1 dependencel misspelling; S13: My mother is a ama de casal L1 dependencel omit verb].["I used my native language because it is pretty difficult to me to use English" (Student's selfreflection)].

["I used my native language in all English classes" (Students' self-reflection)

"Students did not isolate their native language; they mentioned words in L1 most of the time; (teachers' diary).]

As Excerpt 12 point out, learner's issues in decreasing L1 dependence at English class when developing the writing activities still continue. That is, their oral and written participation, generally made in their native language, meant that they had difficulties to learn a foreign language.

\section{Volume 10 Issue 7, July 2021 www.ijsr.net}


Excerpt 12: As I mentioned before, learners did not isolate their native language, they talk between them in Spanish, ask questions to the teacher in Spanish too; they resolve the activities in English, but sometimes words they do not know, write it in Spanish (teachers' diary).

The findings in this section suggest that the learners' L1 writing experiences played a role in shaping their L2 writing perceptions. Learners wanted to solve any problem during a writing activity, omitting some important aspects from L2, and finding support in L1 language to fulfill the assigned tasks.

\section{Discussion and Conclusions}

This study meant to explore the impact of dialogue journals on seventh graders' writing. After the implementation of the research, the results proved an impact reflected in the improvement of learners' writing. This impact is principally due to the application of dialogue journal strategy. This section presents the main conclusions and pedagogical implications derived from those results in order to provide teachers and researchers with useful insights about the applicability of this methodology.

One of the contributions of this study is related to the use of dialogue journals in teenagers, and the improvement of writing as well as the increase of vocabulary, grammar and decrease in L1 use. Students put into practice the vocabulary previously taught in class; they are also able to monitor their own progress and learning. Furthermore, dialogue journal is a strategy "where learners draw on their personal funds of knowledge and make connections between what they know and what they are learning in class" (Uduma 2011). This study confirmed that one of the benefits of dialogue journal in L2 language learners is the development of writing fluency (Holmes \& Moulton, 1997; McGrail, 1996; Peyton, 1990, 2000).

The second contribution of this investigation is in the significance of using meaningful activities for young learners when writing. The participants improved their writing while they worked with their diaries in this study, they were motivated more focused. This study confirms then that dialogue journals recorded ESL students' writing progress, which fosters the students' writing confidence. Dialogue journals can be an effective tool for increasing L2 students' writing confidence during classes (Alexander, 2001).

The impact on students' writing is the third contribution of this research. Additionally, writing new entries and sharing ideas with the teacher about real situations helped the learners to enhance English writing fluency, motivation, and reflective awareness. Thus, with challenging activities, learners increase confidence while writing.

As for writing fluency, the fourth contribution of this study is that dialogue journal benefits learners because it is meaningful and help them gain confidence while writing. Pre-writing activities might be engaging ways to develop fluency, since practicing before writing helps students to better in that skill. Giving learners the chance to write about topics of their interest is important. Thus, teachers can lead and give students the chance to write topics they like and avoid the risk of decreasing their growth (Holmes and Moulton 1997; Larrotta 2008).

The last contribution of this research deals with the fact that dialogue journals are useful for learners' reflective practice and teacher-and-learner interactive engagement (Carroll \& Mchawala, 2001; English \& Gillen, 2001; Peyton, 1993b, 2000; Peyton \& Reed, 1990; Peyton \&Staton, 1993; Reed, 1993; Trites, 2001.) Dialogue journals allow students to have a better writing progress by providing them with the opportunity to interact with their teacher and classmates. This confirms that dialogue journal contributes to learner interaction, letting students use reading and writing in "effective ways and provide a usual, comfortable bridge to alternative kinds of writing" (Peyton, 2000, p. 1).

Additionally, it is important to recognize the limitations of this study. Firstly, certain activities did not match the students level of English. However, those activities were amusing and demanding for them. Secondly, there was an unusual difficulty when students had to write paragraphs, even if they knew the vocabulary and grammatical structures, students were not able to write without guidance. Thirdly, the way in which the strategy was carried out helped learners to write better.

Consequently, dialogue journals, as Reed (1988) suggests are a technique in which young, new language learners can engage in dialogue journal writing to great, linguistic, cognitive, and personal benefit. It is to say, students can exchange personal meaningful ideas, commonly between teacher and themselves, by means of writing new entries in their journals to: practice authentic language, increase their motivation, develop writing and reading fluency, and develop close relationship between the teacher and students (Kose, 2005). For future studies, I recommend future researchers teachers to consider students' needs, since learners do not have the same English level. Future research should delve deeper and consider the students' levels of English and interests, which might affect results related to the effectiveness of the strategy.

Future studies should also consider students' writing English abilities in order to confirm the students' strengths and weaknesses, especially when they write to communicate. Besides, teachers should consider the kind of activities that learners can perform. Teachers and researchers should model ways to appropriately use dialogue journals in order to make this strategy more effective.

\section{References}

[1] Ballantyne, R., \& Packer, J. (1995). Making connections: Using student journals as a teaching/learning aid.

[2] Berman, R. (1994). Learners' transfer of writing skills between languages. TESL Canada Journal, 12(1), 29. https://doi.org/10.18806/tesl.v12i1.642

[3] Cummins, J. (1978). The cognitive development of children in immersion programs. Canadian Modern

\section{Volume 10 Issue 7, July 2021} www.ijsr.net 


Language Review, 34(5), 855-
883.https://doi.org/10.3138/cmlr.34.5.855

[4] Han, F. E. I. F. E. I., \& Stevenson, M. A. R. I. E. (2008). Comprehension monitoring in first and foreign language reading. University of Sydney Papers in TESOL, 3, 73-110.

[5] Harmer, J. (2004). How to teach writing. Recuperado de

https://www.academia.edu/41442986/Jeremy_Harmer_ How_to_Teach_Writing_Longman_2004

[6] Harmer, J. (2007). The practice of English language teaching. : Pearson Longman.

[7] Harris, K. R., Graham, S., and Mason, L. H. (2003). Self-regulated strategy development in the classroom: Part of a balanced approach to writing instruction for students with disabilities. Focus on Exceptional Children, 35(7), 1-16.

[8] Holmes, V.L., and Moulton, M.R. (1997). Dialogue journals as an ESL learning strategy. Journal of Adolescent \& Adult literacy, 40(8), 616-621.

[9] Husain, K. (1995). Assessing the role of translation as a learning strategy in ESL. International Journal of Translation, 1(2): 59-84.

[10] Kose, E. (2005). Impact of Dialog Journals on Language Anxiety and Classroom Affect. Unpublished Master's Thesis. Bilkent University, Ankara, Turkey.

[11] Larrotta, C. (2008). Written conversations with hispanic adults developing english literacy. Adult basic education and literacy journal 2 (1): 13-23.

[12] McGrail, L. (1996). Full cycle: From journal writing to "codes" to writing. In J.K. Peyton \& J. Staton (Eds.), Writing our lives: Reflections on dialogue journal writing with adults learning English (pp. 71-74). Washington, DC and McHenry, IL: Center for Applied Linguistics and Delta Systems.

[13] Orem, R. 2001. Journal writing in adult ESL: Improving practice through reflective writing. New Directions for Adult and Continuing Educa - tion 90: 69-78.

[14] Peng, C.Y. (2007). The effect of online journal writing on writing performance and writing self-efficacy of undergraduate students - A case of Chaoyang University of Technology. Unpublished Master's Thesis, Chaoyange University of Technology. Taichung, ROC.

[15] Peyton, J.K. (1990). Dialogue journal writing and the acquisition of English grammatical morphology. In J.K. Peyton (Ed.), Students and teachers writing together: Perspectives on journal writing (pp. 67-97). Alexandria, VA: Teachers of English to Speakers of Other Languages.

[16] Peyton J.K. (2000). Dialogue journals: Interactive writing to develop language and literacy. ESL Resources: Digests. National Center for ESL Literacy Education. Retrieved October 20, 2009, from http://www.cal.org/caela/esl_resources/

digests/Dialogue_Journals.html

[17] Peyton, J. and Staton, J. (Eds.) (1 993). Dialogue journals in the multilingual classroom: Buildingjluency and writing skills rhroughwrirren interaction. Nonvood, NJ: Ablex.

[18] Seow, A. (2002). The Writing Process and Process Writing. In J. C. Richards, \& W. A. Renandya (Eds.),
Methodology in Language Teaching (315-327). USA: Cambridge University Press.

[19] Trites, L. (2001). Journals as self-evaluative, reflective classroom tools with advanced ESL graduate students. In J.I. Burton \& M. Carroll (Eds.), Journal writing: Case study in TESOL practice series (pp. 59-70). Alexandria, VA: Teachers of English to speakers of Other Languages, Inc. (TESOL)

[20] Yoshihara, R. (2008). The bridge between students and teachers: The effect of dialogue journal writing. Language Teacher, 32(11), 3-7.

Volume 10 Issue 7, July 2021 www.ijsr.net 